\title{
Buying Time with Runnels: a Climate Adaptation Tool for Salt Marshes
}

\author{
Alice F. Besterman ${ }^{1,2}\left(\right.$ D $\cdot$ Rachel W. Jakuba ${ }^{1} \cdot$ Wenley Ferguson $^{3} \cdot$ Diana Brennan $^{4} \cdot$ Joseph E. Costa $^{5}$. \\ Linda A. Deegan ${ }^{2}$
}

Received: 13 July 2021 / Revised: 29 October 2021 / Accepted: 8 November 2021 / Published online: 1 January 2022

(c) The Author(s) 2021, corrected publication 2022

\begin{abstract}
A prominent form of salt marsh loss is interior conversion to open water, driven by sea level rise in interaction with human activity and other stressors. Persistent inundation drowns vegetation and contributes to open water conversion in salt marsh interiors. Runnels are shallow channels originally developed in Australia to control mosquitoes by draining standing water, but recently used to restore marsh vegetation in the USA. Documentation on runnel efficacy is not widely available; yet over the past 10 years dozens of coastal adaptation projects in the northeastern USA have incorporated runnels. To better understand the efficacy of runnels used for restoration, we organized a workshop of 70 experts and stakeholders in coastal resource management. Through the workshop we developed a collective understanding of how runnels might be used to slow or reverse open water conversion, and identified unresolved questions. In this paper we present a synthesis of workshop discussions and results from a promising case study in which vegetation was restored at a degraded marsh within a few years of runnel construction. Despite case study outcomes, key questions remain on long-term runnel efficacy in marshes differing in elevation, tidal range, and management history. Runnel construction is unlikely to improve long-term marsh resilience alone, as it cannot address underlying causes of open water conversion. As a part of holistic climate planning that includes other management interventions, runnels may "buy time" for salt marshes to respond to management action, or adapt to sea level rise.
\end{abstract}

Keywords Runnel $\cdot$ Salt marsh $\cdot$ Sea level rise $\cdot$ Shallow water $\cdot$ Climate adaptation $\cdot$ Coastal restoration

\section{Introduction}

While for centuries salt marsh loss was driven by direct human alterations (Gedan et al. 2009), sea level rise (SLR) now poses one of the chief threats to salt marshes globally (FitzGerald and Hughes 2019; Bindoff et al. in press). Direct alterations (e.g., draining, filling) led to prolific reductions in the global inventory of salt marshes (Gedan et al. 2009;

Communicated by Kenneth L. Heck

Alice F. Besterman

abesterman@woodwellclimate.org

Buzzards Bay Coalition, New Bedford, MA, USA

2 Woodwell Climate Research Center, Falmouth, MA, USA

3 Save the Bay, Providence, RI, USA

4 Bristol Country Mosquito Control Project, Attleboro, MA, USA

5 Buzzards Bay National Estuary Program, Mattapoisett, MA, USA
Mcowen et al. 2017). Regulations have mitigated direct loss of wetlands along many temperate coastlines (Gedan et al. 2009; Bindoff et al. in press); however, legacy impacts from agriculture (Adamowicz et al. 2020) and mosquito ditching (Vincent et al. 2014; Burdick et al. 2020), in interaction with SLR (Raposa et al. 2017; Watson et al. 2017), continue to alter hydrology and stress vegetation. A primary manifestation of these stressors in Northwest Atlantic and Mississippi Delta marshes has been the expansion of unvegetated, shallow water features in marsh interiors, i.e., open water conversion (Barras et al. 2003; La Peyre et al. 2009; Vincent et al. 2014; Kearney and Turner 2016; Watson et al. 2017; Adamowicz et al. 2020) (Fig. 1c-e). Globally, salt marsh coverage is most extensive in low-lying temperate zones of the North Atlantic (Mcowen et al. 2017). Thus, marsh losses to open water conversion in this region are globally significant.

A surge in restoration of Northwest Atlantic salt marshes (specifically, northeastern USA) occurred over the past decade, funded by the US government in the 
Fig. 1 a Salt marsh ecosystems support wildlife, e.g., great egrets (Casmerodius albus) and b saltmarsh sparrows (Ammospiza caudacuta). c Salt marsh interiors increasingly impacted by sea level rise, in interaction with legacy effects from human activity, are experiencing plant death and drowning. d Plant death is recent; with short, stressed vegetation and intact peat present with impounded water and $\mathbf{e}$ and algal mats. $\mathbf{f}$ Dead killifish (Fundulus heteroclitus) stranded when a shallow water area is drained

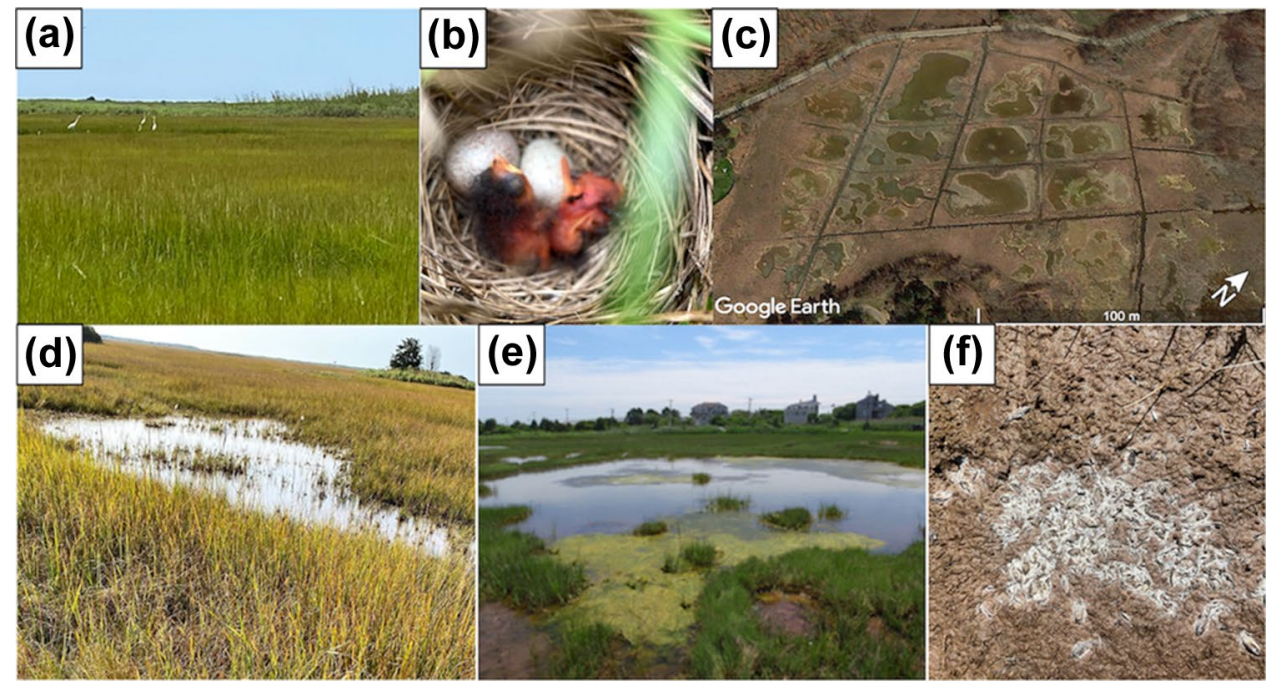

aftermath of Superstorm Sandy in 2012 (Babson et al. 2020). One technique involved digging "runnels"-small channels meant to drain standing water and promote revegetation (Wigand et al. 2017; Raposa et al. 2019; Babson et al. 2020; Perry et al. 2021; Wolfe et al. 2021). As of 2019 , knowledge on runnel efficacy as a tool to build marsh resilience to SLR (defined here as the ability of a marsh to resist a state-change to open water) had not been widely shared. Recognizing the need to critically evaluate runnels as a climate adaptation tool, we organized a workshop on the runnel technique in early 2020. Workshop goals were to solicit expert opinion on the practice of runnelling and to build consensus around when and how to use runnels. This information was used to design our own experimental test of runnels, which is now underway. Seventy people including scientists, regulators, landowners, and resource managers from government, academia, and non-profits participated. During the workshop, scientists and managers presented outcomes from recent runnelprojects, followed by panel and small group discussions.

This paper is a product of the workshop, subsequent engagement among participants, and literature review. Three focal questions will be discussed here: (Q1) What problem do managers use runnels to address? (Q2) What is a runnel and how does it work? and (Q3) How effective are runnels? We focus on runnel use to mitigate marsh loss caused by interior shallow water expansion, describe runnel mechanics and present a case study, and discuss lessons learned on efficacy and remaining knowledge gaps. To address remaining gaps, we present specific research topics needing attention. We synthesized information from workshop presentations and subsequent engagement, and literature review to address all three questions. We used the case study to supplement our discussion of Q2 and Q3.

\section{The Problem: Changing Hydrologic Dynamics}

Pre-colonial salt marsh hydrology in the Northwest Atlantic featured networks of channels, as well as isolated pannes and pools (Redfield 1972). "Single-channel" hydrology included a primary channel intersected by dendritic tributaries draining the platform (Redfield 1972). Pannes and pools dot marsh platforms and create habitat for unique plants, fish, and waterbirds (Fig. 1a). These features were classically considered in dynamic equilibrium with the vegetated platform (Ewanchuk and Bertness 2004; Adamowicz and Roman 2005; Wilson et al. 2014; Adamowicz et al. 2020). Pannes are shallow depressions with waterlogged soils covered with sparse forbs and bare sediment that form and revegetate within a few years (Ewanchuk and Bertness 2004). Pools are deeper depressions that remain flooded and enlarge, and may drain and revegetate slowly over decades to centuries (Adamowicz and Roman 2005; Wilson et al. 2014).

A natural cycle of "pool recovery," also applicable to shallow pannes, has been documented in some marshes (Wilson et al. 2014; Mariotti 2016). Pools form and expand until they connect to a headward eroding creek that drains the pool. After pool drainage, the remaining bare peat area revegetates. Theoretical models suggest that a large tidal range $(>1 \mathrm{~m})$, large sediment supply $(>70 \mathrm{mg} / \mathrm{L})$, and accretion rates equal to or greater than relative SLR (RSLR) favor pool recovery (Mariotti 2016). Empirical work has shown that pool recovery can occur without satisfying all criteria (Smith and Pellew 2021). The idealized conditions promote pool recovery by maintaining marsh elevation such that unvegetated basins of pools and pannes are suitable for vegetative growth relative to 
local sea level. If these unvegetated pool and panne basins become too low in relative elevation to revegetate, then pool recovery cannot occur. Without dynamic recovery, pool and panne expansion may lead to the conversion of marsh interiors to open water (Kearney and Turner 2016; Mariotti 2016; Himmelstein et al. 2021).

Recent studies report the expansion of bare and shallow water areas on marsh surfaces across the Northwestern Atlantic (Table 1). In Mississippi Delta marshes, the formation and expansion of interior pools has been contributing to marsh loss for decades (DeLaune et al. 1994; Barras et al. 2003). While pannes and pools were not classically considered to contribute to net marsh loss (Ewanchuk and Bertness 2004; Adamowicz and Roman 2005), observed increases in the number and size of unvegetated features suggest that marsh hydrology is not in equilibrium - and a trend toward net conversion of vegetated marsh to bare and shallow water areas (Table 1, and references therein). In North America, pre-colonial salt marsh hydrology was altered by colonial farmers, and later for mosquito control (Vincent et al. 2014; Adamowicz et al. 2020). Historic modifications to marshes including ditches, side-cast ditch spoils that form artificial levees, ditch-plugs, and embankments altered topography and hydrology, lowering resilience to current stress from SLR. Ditching lowered marsh platform elevations (Burdick et al. 2020), while artificial levees, embankments, and ditch-plugs created microtopographic impoundments that block natural water flow pathways (Vincent et al. 2014; Adamowicz et al. 2020; Wolfe et al. 2021). Increased inundation from SLR, in interaction with lowered platform elevations and impaired drainage, have lengthened hydroperiods and likely contributed to the recently observed increases in bare and shallow water areas within marshes (Fig. 2a-c) (Adamowicz et al. 2020; Himmelstein et al. 2021; Wolfe et al. 2021). Ecosystem managers have observed that vegetation communities in recently developed bare and shallow water areas do not resemble the diversity of "forb pannes" expected for northern New England (Ewanchuk and Bertness 2004, personal communication). Water depths in these recently developed areas appear intermediate between pannes and pools, creating conditions inhospitable to vegetation (Fig. 1d, e), but too shallow or hypersaline to support fish (Fig. 1f). Understanding whether marsh ecosystem function and resilience are being permanently altered depends on the trajectory of these shallow water areas.

Mariotti (2016) proposed a framework of shallow water expansion that described three scenarios: "pool recovery" (described above), "drowning," and "pool collapse." Drowning occurs when water becomes impounded on the marsh platform and stresses vegetation (Mariotti 2016). Plant death and peat subsidence follow, initiating a positive feedback cycle of water expansion (DeLaune et al. 1994; Chambers et al. 2019). Marsh drowning is predicted for marshes where 
Fig. 2 (a) Marshes with environmental conditions that favor conversion to open water are experiencing (b) longer periods of inundation on marsh interiors and (c) standing shallow water on marsh platforms (Winnapaug marsh, RI). If no action is taken, expanding shallow water leads to (c1) open water or (c2) pool collapse. If a (c3) runnel is created, (d) surface water should drain allowing revegetation (Winnapaug marsh, RI). But without changing the conditions that led to shallow water formation, (e) what is the long-term trajectory of runnel-adapted marshes?

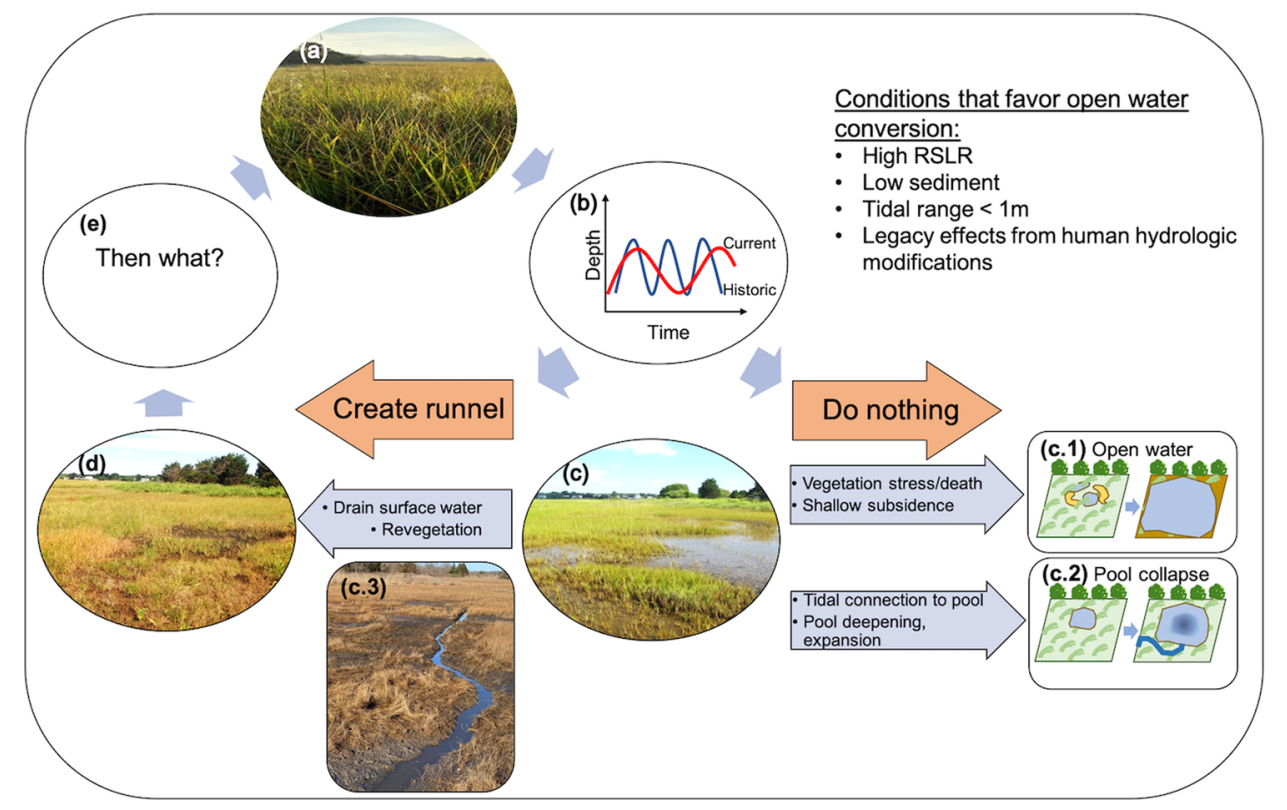

RSLR is high ( $>10 \mathrm{~mm} \mathrm{yr}^{-1}$ ), and the entire platform is accreting at less than RSLR. Pool collapse involves a pool becoming tidally connected by a creek, similar to pool recovery, except the pool expands and deepens (Mariotti 2016; Schepers et al. 2020). This may occur when the pool basin elevation is too low relative to sea level for vegetation to recover. Instead of drainage, tidal water conveyed by the creek can erode unconsolidated material underlying pools (Schepers et al. 2020). Pool collapse happens when the marsh platform keeps pace with RSLR, but the basin of the pool does not, and can occur at lower rates of RSLR than drowning (5-8 $\left.\mathrm{mm} \mathrm{yr}^{-1}\right)$. Rates of RSLR capable of inducing pool collapse are higher than current SLR (3-4 $\mathrm{mm} \mathrm{yr}^{-1}$ ) experienced by the majority of marshes globally (Oppenheimer et al. in press). Other factors in addition to RSLR are important in determining whether a shallow water area proceeds along a collapse or recovery trajectory. The likelihood of pool collapse may increase with a smaller tide range, lower sediment supply, and when a larger volume of water is conveyed through the connecting creek (Mariotti 2016; Schepers et al. 2020). As a result, drowning and pool collapse are two mechanisms by which interior vegetated marsh areas convert to shallow water and contribute to marsh loss.

Researchers and resource managers have recently pointed to the widespread increase of interior shallow water as an indicator of marsh loss (Watson et al. 2017; Campbell and Wang 2019; Adamowicz et al. 2020; Schepers et al. 2020; Taylor et al. 2020; Duran Vinent et al. 2021; Himmelstein et al. 2021), and have responded with management actions to stop or slow open water conversion (Wigand et al. 2017; Raposa et al. 2019; Adamowicz et al. 2020; Babson et al. 2020; Perry et al. 2021; Wolfe et al. 2021). However, in some marshes an increase in standing surface water could represent a recovery of "natural" hydrology after marshes were historically over-drained by ditches, and some marshes show potential for pool recovery (Wilson et al. 2014; Smith and Pellew 2021). While these recovery scenarios may occur in some places, coasts with low sediment supply or small tidal ranges, and where legacy effects of agriculture and ditching have altered hydrology are unlikely to follow these trajectories (Mariotti 2016; Adamowicz et al. 2020; Wolfe et al. 2021). Rather, increasing periods of inundation will likely lead to drowning, pool collapse, or another mechanism of open water conversion (Fig. 2). In these marshes with low recovery potential, managers are using runnels as a low-cost tool to address increasing surface water and restore vegetation (Table 2 and Supplemental File 1).

\section{Introducing Runnels: History and Progress}

\section{Runnels as a Climate Adaptation Tool}

Runnels used for climate adaptation to SLR are a new application of an existing mosquito control technique used in the USA and Australia (Hulsman et al. 1989; Wolfe 1996). Historic mosquito ditches were excavated $>60 \mathrm{~cm}$ deep, causing peat oxidation and subsidence of the inter-ditch marsh platform (Burdick et al. 2020). More recently, mosquito control programs began constructing runnels that resembled natural channels to drain standing water (mosquito larvae habitat) and allow fish passage (mosquito larvae predators), with minimal impact to marshes (Hulsman et al. 1989).

A runnel is a small channel (generally $\leq 30 \mathrm{~cm}$ wide and deep) that drains standing water on the marsh surface. Runnels are constructed using hand-digging and low-ground 
Table 2 Selected runnel adaptation projects from the northeastern USA The table includes the year each project was initiated, project name and location, the closest NOAA tide station and tidal range and

\begin{tabular}{|c|c|c|c|c|c|c|c|}
\hline Year & Project name & NOAA station & $\begin{array}{l}\text { Tidal range } \\
\text { (m) }\end{array}$ & $\begin{array}{l}\text { Sea level } \\
\text { rise }(\mathrm{mm} / \\
\text { yr) }\end{array}$ & Motivations & $\begin{array}{l}\text { No. of } \\
\text { runnels }\end{array}$ & $\begin{array}{l}\text { Vegetation } \\
\text { response }\end{array}$ \\
\hline 2004 & $\begin{array}{l}\text { Mile Creek Marsh A } \\
41.28,-72.29\end{array}$ & Bridgeport, CT & 2.05 & 3.08 & $\begin{array}{l}\text { Revegetate dieback, } \\
\text { mosquito control }\end{array}$ & 2 & After $2-5$ years \\
\hline 2014 & $\begin{array}{l}\text { Round Marsh } \\
41.51,-71.37\end{array}$ & Newport, RI & 1.05 & 2.83 & $\begin{array}{c}\text { Phragmites control, } \\
\text { mosquito control }\end{array}$ & 8 & After 1 year \\
\hline 2014 & $\begin{array}{l}\text { Mile Creek Marsh B } \\
41.28,-72.29\end{array}$ & Bridgeport, CT & 2.05 & 3.08 & $\begin{array}{l}\text { Revegetate dieback, } \\
\text { wildlife habitat }\end{array}$ & 4 & After 1 year \\
\hline 2015 & $\begin{array}{l}\text { Parker River NWR, } \\
\text { Ditch Plug Removal } \\
42.78,-70.81\end{array}$ & Boston, MA & 2.89 & 2.87 & $\begin{array}{l}\text { Revegetate dieback, } \\
\text { low-marsh to high- } \\
\text { marsh species }\end{array}$ & 22 & After 1 year \\
\hline 2017 & $\begin{array}{l}\text { Reeds Beach at Cape } \\
\text { May National } \\
\text { Wildlife Refuge } \\
39.12,-74.88\end{array}$ & Cape May, NJ & 1.48 & 4.88 & $\begin{array}{l}\text { Low-marsh to high- } \\
\text { marsh species, } \\
\text { wildlife habitat }\end{array}$ & 40 & After 1 year \\
\hline 2018 & $\begin{array}{l}\text { Potters Pond } \\
41.38,-71.53\end{array}$ & Newport, RI & 1.05 & 2.83 & $\begin{array}{l}\text { Revegetate dieback, } \\
\text { mosquito control }\end{array}$ & 7 & After $2-5$ years \\
\hline 2019 & $\begin{array}{l}\text { Furbish Marsh } \\
\text { Restoration } \\
43.28,-70.58\end{array}$ & Seavey Island, ME & 2.47 & 2.05 & $\begin{array}{l}\text { Revegetate dieback, } \\
\text { low-marsh to high- } \\
\text { marsh species }\end{array}$ & 2 & No results yet \\
\hline 2019 & $\begin{array}{l}\text { NFWF Gardiners } \\
40.69,-73.27\end{array}$ & Sandy Hook, NJ & 1.43 & 4.15 & $\begin{array}{l}\text { Revegetate dieback, } \\
\text { low-marsh to high- } \\
\text { marsh species }\end{array}$ & 40 & After 1 year \\
\hline 2020 & $\begin{array}{l}\text { Little Bay } \\
\text { Conservation Area } \\
41.63,-70.87\end{array}$ & Newport, RI & 1.05 & 2.83 & $\begin{array}{l}\text { Research and } \\
\text { assessment, } \\
\text { revegetate dieback }\end{array}$ & 5 & No results yet \\
\hline 2020 & $\begin{array}{l}\text { Ocean View Farm } \\
41.52,-71.00\end{array}$ & Newport, RI & 1.05 & 2.83 & $\begin{array}{l}\text { Research and } \\
\text { assessment, } \\
\text { revegetate dieback }\end{array}$ & 7 & No results yet \\
\hline 2020 & $\begin{array}{l}\text { Smith Point } \\
40.74,-72.88\end{array}$ & Sandy Hook, NJ & 1.43 & 4.15 & $\begin{array}{l}\text { Mosquito control, } \\
\text { revegetate dieback }\end{array}$ & 56 & No results yet \\
\hline
\end{tabular}

SLR reported for that station, primary motivations for the project, the tion response to runnels number of runnels used in the project (if known), and general vegeta- pressure excavators or ditchers (Supplemental File 1) to follow topographical low areas, and only drain water within the rooting zone (Hulsman et al. 1989; Wigand et al. 2017). Runnels are similar in principle to tidal creek extension projects that connect an area of inundation to the tidal creek network, though tidal creek extensions are larger in scale than runnels (Raposa et al. 2019; Taylor et al. 2020; Wetland restoration at Farm Creek Marsh 2021). After observing rapid expansion of shallow water within northeastern US marshes, restoration ecologists began working with mosquito control agencies to use runnels for the dual purpose of mosquito abatement and marsh adaptation to SLR. Practitioners used the technique to target shallow water features that were expanding, had formed within the last few decades, and where an anthropogenic topographic feature was impairing water flow (ditch spoils, plugged ditches, embankments) (Wigand et al. 2017; Adamowicz et al. 2020; Perry et al. 2021; Wolfe et al. 2021). True ponds that remained flooded throughout the tide cycle, with unconsolidated sediments in the basin, and that appeared stable in dimension on decadal timescales, were not targeted with this technique (workshop communications). Save the Bay (STB), an environmental non-profit, launched a series of projects using runnels in Rhode Island (RI), USA beginning in 2010. In our 2020 workshop, resource managers reported projects on dozens of marshes across six northeastern US states, and another half dozen northeastern and mid-Atlantic marshes were under consideration for runnel-adaptation by land trusts, NGOs, and government agencies (Supplemental File 1). The majority of projects from the workshop, and one recently published study on runnels (Perry et al. 2021), have reported some vegetation recovery within 1-5 years (Table 2 and Supplemental File 1).

\section{Runnel Case Study: Winnapaug Marsh, RI}

An STB restoration project provides a case study on patterns of vegetation recovery. We selected this project because it has the longest monitoring record (8 years) of the STB 
projects, including pre-treatment data. Habitat restoration using runnels can be summarized by three phases. Phase I: "Drainage" is characterized by a loss of standing surface water. Phase II: "Early colonizers" is characterized by bare sediment which is colonized by Salicornia spp. and Spartina alterniflora. Phase III: "High-marsh species" is characterized by Distichlis spicata, Spartina patens, and Juncus gerardii succeeding early colonizers.

Winnapaug back barrier salt marsh in RI $\left(41.3306^{\circ} \mathrm{N},-\right.$ $71.7684^{\circ} \mathrm{W}$ ) is a grid-ditched marsh with significant surface water cover and platform degradation (Fig. 3). Tidal range at the nearest tide station in Newport, RI is $1.05 \mathrm{~m}$; however, tidal amplitudes are restricted in back-barrier environments such as Winnapaug. Ditches were created during the 1930s, and peat spoils were placed along ditch edges, creating linear impoundments. Altered topography in combination with RSLR in RI (5.26 $\mathrm{mm} \mathrm{yr}^{-1}$ between 1999 and 2015) (Raposa et al. 2017) led to the "waffle-maple-syrup" pattern (Adamowicz et al. 2020) seen in aerial imagery (Fig. 3). As of 2011, large mats of filamentous algae were growing in shallow water areas (Fig. 1e), and mosquito larvae were observed. Initial depths of shallow water areas ranged from a few centimeters up to about $25 \mathrm{~cm}$ and were generally less than $15 \mathrm{~cm}$ deep.

STB and Town of Westerly, RI, secured funds and permits to create runnels targeting shallow water areas. Environmental and vegetation monitoring was conducted prior to runnel creation in 2011, and post-implementation monitoring was repeated in 2013-2015, 2017, and 2019. Initial hand excavation of a few small runnels began in summer 2012 . In May 2013, STB and RI Department of Environmental Management's Mosquito Abatement Program used a lowground pressure excavator to expand the runnel network, and volunteers hand dug smaller runnels. Clogged mosquito ditches were cleared, and the material was used to fill selected ditches and degraded areas. Hand digging continued in 2013-2014 to facilitate additional drainage. In total, around 33 runnels were created ranging from 2 to $8 \mathrm{~m}$ in length. Runnel widths ranged from 10 to $24 \mathrm{~cm}$, and depths ranged from 10 to $18 \mathrm{~cm}$.

Surveys of vegetation and surface water were conducted using quadrat sampling along transects (Roman et al. 2001). Vegetation and ground cover was estimated as percent cover of each transect (Fig. 3). In the text below, transect data was aggregated to present coverages by species or cover type for the entire marsh. Initially (2011), algal mats covered 44\%, open water $14 \%$, and bare peat $4.5 \%$ of the marsh platform. The marsh was dominated (57\% cover) by Spartina alterniflora, a species which tolerates frequent inundation (Fig. 3). Less-flood tolerant, "high-marsh" species included Distichlis spicata (26\%), Spartina patens (18\%), and Juncus gerardii $(2.7 \%)$.

Ecosystem responses to runnels proceeded as across the marsh (Fig. 4). During Phase I open water decreased to $5 \%$ by 2013 , and was absent in 2014 across the entire marsh. Algal mats disappeared by 2013. During Phase II,
Fig. 3 Vegetation change shown as percent cover for Winnapaug transects (T1, T2, T3 bar plots) with runnelling (*excavation years) displayed over aerial imagery from 2011. Species in legend are ordered from most tolerant of inundation (purple - Salicornia) to least tolerant (yellow - Iva), and transects shown as black lines. White arrows indicate respective vegetation cover data. T2 and T3 had significantly greater surface water than $\mathrm{T} 1$ to begin with, and $\mathrm{T} 1$ had greater recolonization of high-marsh species than $\mathrm{T} 2$ or T3
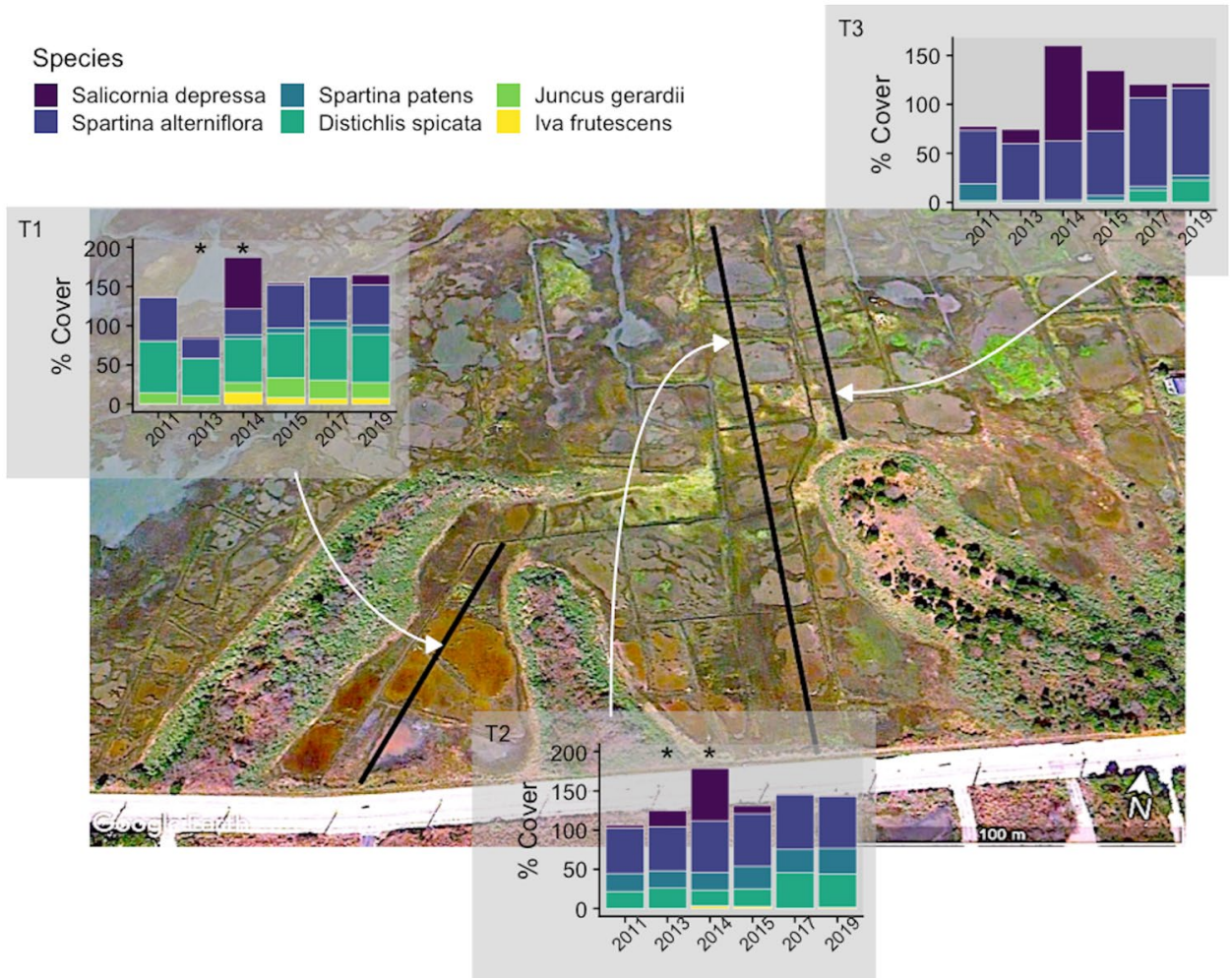
Fig. 4 Recovery of Winnapaug marsh after runnelling shown for a low elevation, T2 in Fig. 3, and b high elevation, T1 in Fig. 3, areas. Elevation was inferred from water table monitoring. Ground and species percent cover shown relative to runnel construction timeline on $x$ axis. First dashed line (2012) indicates when digging began; excavation continued through 2014 ("Runnels complete"). Monitoring dates listed in text. Note that Phases I and II occurred simultaneously, and Phase III occurred sooner along the high-elevation transect

\section{Marsh recovery with runnel adaptation}
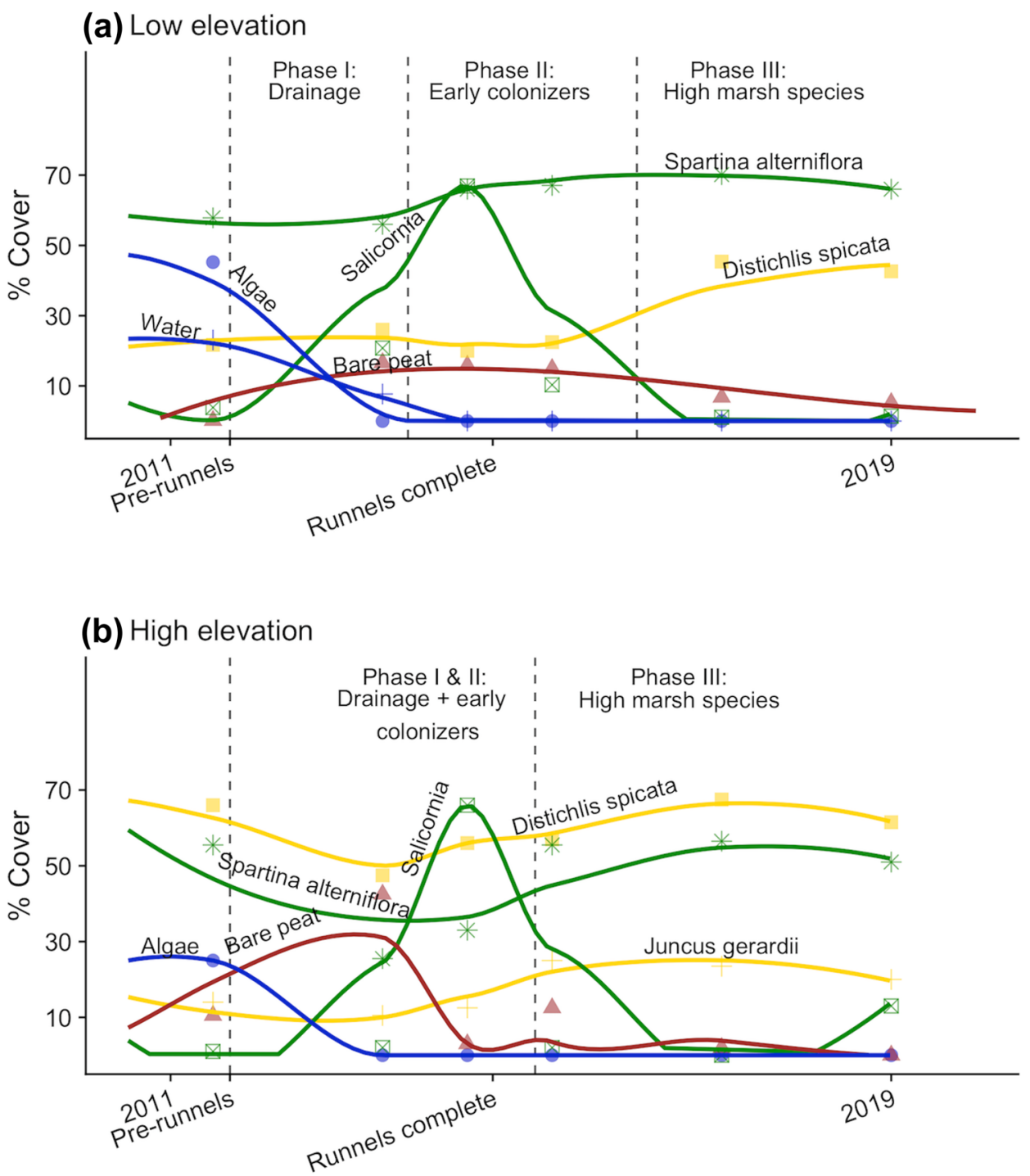

Time series bare peat initially increased as water drained from the site (maximum of $26 \%$ by 2013), but then declined (3.2\% by 2019) as areas were recolonized. Salicornia depressa, a flood-tolerant, early-colonizing species, increased rapidly from $3.3 \%$ prior to runnels to $73 \%$ in 2 years (2014). Salicornia then declined to $4.3 \%$ by 2019 as less flood-tolerant, high-marsh species increased. After 3 years (2015), Phase III-high marsh species began to increase. After 7 years (2019), Distichlis had increased to $42 \%$ cover, Spartina patens to 24\% cover, and Juncus to 3.8\%. Spartina alterniflora remained the dominant cover, increasing to $65 \%$ cover after 3 years, and 68\% after 7 years (2019). The increase in vegetation, especially high-marsh species, suggests that runnels have potential for short-term restoration of marsh plants.

While vegetation recovered across the marsh on the whole, responses differed across the marsh. Platform elevations along transect $\mathrm{T} 1$ were conducive to high-marsh species growth prior to runnel creation; as a result, draining the shallow water areas allowed bare peat to recolonize with high-marsh species quickly (Fig. 3). In contrast, the shallow water areas at the northern ends of transects T2 and T3 (Fig. 3) showed minimal response to runnels. Water levels decreased, but the features never fully drained and vegetation did not recover. As a result, T2 and T3 vegetation responses differed from T1 (Fig. 3). Based on water table monitoring 
(Supplemental File 2), STB believes that basin elevations in some of the northern shallow water areas were too low in elevation for vegetation to recover. Long-term monitoring at this and other runnel project sites is important for assessing which marshes are good candidates for runnels, and how much time we can "buy" using this technique (a few years, decades, or more).

\section{Efficacy of Runnels: Can We Buy Time for Salt Marshes?}

Runnels have promise as a climate adaptation technique. Practitioner experiences shared at our 2020 workshop suggest that runnels will be most effective in higher elevation areas, and where peat is less degraded with root mats still intact and still firm within shallow water areas. Since only a few of the resource management projects that have used runnels included experimental designs or extensive data collection, work is still needed to statistically test runnel efficacy (Table 2 and Supplemental File 1). As a result, first-order questions remain on how responses in vegetation and the spatial footprint of a single runnel vary across a range of elevations, degradation levels (extent of elevation loss and peat decomposition within shallow water areas), tidal ranges, and suspended sediment concentrations. Key second-order questions remain as well, including when runnels risk triggering pool collapse, which ecosystem services are improved, if peat oxidation ever occurs, and, most critically, whether runnels can rebuild long-term resilience of salt marshes.

In 2020, our team launched an experiment to test runnels and address a set of these first- and second-order questions. We established 20 study sites (10 treatment, 10 control) at a range of elevations and degradation levels across two marsh complexes (Little Bay Conservation Area and Ocean View Farm; Table 2) using a replicated-BACI design. We are monitoring responses in vegetation, hydrology, soil properties, elevation, and decomposition, as well as a suite of baseline environmental characteristics. With this study, we will measure the rate of vegetation recovery and the spatial footprint of runnels and determine how hydrologic and vegetation responses differ along gradients of elevation and degradation. However, tidal range $(\sim 1 \mathrm{~m})$ and suspended sediment concentrations (low) are similar at all our sites, so future studies will be needed to assess runnel efficacy along those gradients. Below, we discuss second-order questions on runnels, how our study is helping to answer them, and where future research is needed.

\section{Avoiding Pool Collapse}

Pool collapse could result from creating a runnel if the basin of a shallow water area is too low in elevation for revegetation, if RSLR is faster than the accretion rate in the basin, or if too little suspended sediment is available for drained shallow water areas to accrete. While creating a runnel into a basin that is too low in elevation should be avoided, cases may exist where a resource manager does not have access to elevation data, or where the threshold elevation for revegetation is unknown. To avoid undesirable outcomes, practitioners manage water volumes flowing out of and into the shallow water area with sills, and by creating runnels in phases. Sills are shallow runnel segments that function as "speed bumps" to slow water velocity, and trap any unconsolidated material that could erode out of shallow water areas after runnel installation. Sills are created by shallower excavation or leaving unexcavated platform, while retaining positive drainage. Sills between runnel terminus and the connecting creek are important when larger tidal channels or high winds could expose bare soil to erosive energy. Runnel construction has been used as an adaptive management approach (Williams 2011), using phased construction to avoid erosion. After initial construction, managers evaluate drainage, and redistribute any sediment trapped in the runnel across the marsh platform. Removing unconsolidated sediment from the runnel avoids plugs forming, and conserves sediment which is a limited resource in many northeastern US marsh systems. Continued excavation is usually required to fully drain standing water. These approaches are encouraged by practitioners even when risks of pool collapse are not obvious, as they also help to avoid over-draining marshes with too much excavation at once. Long-term monitoring is still needed to determine whether pool collapse can be prevented in microtidal, low-sediment marshes with runnels.

\section{Ecosystem Services}

Observations suggest functional improvement of marshes after runnel construction. After 2016 excavated peat has been used to create small "islands" of elevated habitat for nesting saltmarsh sparrows (Ammospiza caudacuta; Fig. 1b), and other birds. Formerly these spoils were required under federal permits to be disposed in upland areas. Authors have observed sparrows nesting in areas drained by runnels shortly after creation. Small killifish (Fundulus heteroclitus) use runnels to access new foraging habitat, sometimes within hours of excavation. Invasive Phragmites australis, which outcompetes resident vegetation (but has a low salt tolerance), can be reduced in height and density by draining freshwater with runnels. Surveys of vegetation and wildlife before and after runnel creation are needed to understand the extent and longevity of habitat improvements. Research on other ecosystem services potentially affected by runnels 
including nutrient cycling and organic matter storage is still needed.

\section{Risk of Peat Oxidation}

Over-draining marshes (e.g., with deep ditches) can lead to peat oxidation and platform subsidence (Burdick et al. 2020). Elevation losses worsen flooding stress from RSLR, and contribute to open-water conversion (Ganju et al. 2020). Runnels are designed to emulate naturally formed channels and avoid over-draining soils by only lowering water in the root zone. Water measurements from Winnapaug runnel sites show that the water table remained within a few centimeters of the soil surface (Supplemental File 2), suggesting minimal risk of over-draining from the shallow runnels used at this site. Further, one study found no increase in $\mathrm{CO}_{2}$ emissions after installing runnels, suggesting that peat oxidation rates did not change (Perry et al. 2021). Overdraining soils could limit recovery of target vegetation species as well. A review of tidally restored marshes in Connecticut, USA found improved vegetation recovery when mean water tables were $24 \mathrm{~cm}$ below the marsh surface over cases with deeper water tables ( $29 \mathrm{~cm}$ below) (Warren et al. 2002). With a maximum runnel depth of $30 \mathrm{~cm}$ used in runnel projects ( $20 \mathrm{~cm}$ in some cases), we suggest that there is generally little risk of peat oxidation or creating inhospitable conditions for target vegetation species with runnels. Further research investigating how runnels impact soil saturation, decomposition, and resultant elevation is needed. In our current experimental work, we are measuring decomposition rates and monitoring hydroperiod, water table, elevation, and redox of marshes before and after runnel creation to address some of these questions.

\section{Runnels and Long-Term Resilience of Marshes}

Short-term responses to runnel construction are encouraging, but long-term ecosystem responses are uncertain. Runnels are proposed to imitate pool recovery in marshes where it may not otherwise occur by draining standing water and facilitating revegetation. They "buy time" for marshes to naturally adapt to SLR by vertical accretion or upland migration, or for additional intervention by managers to occur. However, empirical knowledge of critical thresholds past which marshes cannot recover from an open water conversion trajectory is sparse. As pool recovery occurs with large tidal ranges and high sediment loads, it remains unclear if runnels will be effective without these characteristics over the long term. The volume of tidal water flowing through a runnel and whether water drains fully from a shallow water area are critical variables that will define effectiveness - whether an area revegetates or deepens to a become a permanent pool
(Mariotti 2016; Schepers et al. 2020). Evident in this discussion is the need for a clear understanding of runnels from both theoretical and mechanistic perspectives.

Conditions that reduce marsh resilience to RSLR, specifically, low tidal range, low sediment supply, and low elevation capital, are not changed by runnel creation. Microtidal marshes are particularly vulnerable, where low tidal range corresponds with low sedimentation rates and reduced elevation capital as compared to mesotidal and macrotidal systems (Kearney and Turner 2016). These marshes are still vulnerable to drowning without an external sediment source (Kearney and Turner 2016; Ganju et al. 2020), or compensatory upland space to migrate (FitzGerald and Hughes 2019). Thus, runnels are unlikely to improve longterm marsh resilience to RSLR without additional adaptation strategies, e.g., marsh migration facilitation and sediment placement (La Peyre et al. 2009; FitzGerald and Hughes 2019). Facilitating marsh migration has been attempted by conserving marsh-adjacent habitats and removing humanmade barriers. Other techniques include digging runnels into bordering freshwater wetlands, and "terracing" techniques have been proposed (Salt marsh bird conservation plan for the Atlantic Coast 2019). Sediment placement can compensate for low sediment supply by increasing elevation capital (La Peyre et al. 2009; Salt marsh bird conservation plan for the Atlantic Coast 2019). While additional adaptive action is likely required for marshes to persist, neither sediment placement nor marsh migration will be successful if marsh hydrology is severely compromised. Sediment additions into shallow water areas without facilitating drainage are unlikely to revegetate because waterlogged soil conditions will not support plant growth. Marsh migration into adjacent habitats occurs within a narrow range of elevation. If marsh just below this is stressed by flooding or has converted to open water, then migration is restricted. Runnels will not save salt marshes alone, but by helping salt marsh vegetation recover they complement other approaches.

\section{Conclusions: Runnels and Resilience}

The rate of marsh loss during the past few decades has raised alarm among managers, landowners, and communities who began urgently seeking solutions. In response to interior drowning of northeastern US marshes, ecosystem managers are using runnels to drain water and restore vegetation. Runnel projects proceeded without systematic examination of the conditions in which runnels are most effective or appropriate. Practitioners, regulators, and scientists alike have called for an evaluation of runnel projects to better inform management and funding decisions. Our workshop connected stakeholders and scientists to stimulate knowledge sharing on the runnel technique. In this paper, 
we synthesized those discussions to document current consensus on runnel practice and known efficacy. While initial projects have shown runnels can facilitate revegetation of degraded marshes under some conditions, interactions with elevation and tide range are just a few of the factors needing assessment to include runnels in holistic adaptive planning to restore marsh habitat, and improve salt marsh resilience.

Supplementary Information The online version contains supplementary material available at https://doi.org/10.1007/s12237-021-01028-8.

Acknowledgements We thank all participants in our "Evaluating runnels for Salt Marsh Adaptation" workshop who provided invaluable perspective and knowledge. Special thanks to presenters and panelists: Susan Adamowicz, David Burdick, Tom Iwanejko, and Joseph Montesano. We thank Woodwell Climate Research Center for providing space and support for the event. Thank you to two anonymous reviewers for the feedback that improved the manuscript. Funding for the Winnapaug, RI marsh project was provided by the U.S. Fish and Wildlife Service Coastal Program, and RI Coastal and Estuarine Habitat Restoration Trust Fund. Site access and project facilitation were provided by the Town of Westerly, RI Department of Environmental Monitoring, and STB volunteers and interns. Support for this paper was provided by a Southeast New England Program (SNEP) Watershed Grant funded by the U.S. Environmental Protection Agency (EPA) and by EPA under Cooperative Agreements CE-00A00515 and CE-00A00623 to the Massachusetts Executive Office of Energy and Environmental Affairs. This research was also funded by the U.S. Geological Survey (USGS) Northeast Climate Adaptation Science Center (NE CASC) by Cooperative Agreement G21AC10192-00. Work was also supported by the National Science Foundation DEB-1902712. The views and conclusions contained in this document are those of the authors and should not be interpreted as representing the opinions or policies of the USGS or the EPA. Mention of trade names or commercial products does not constitute their endorsement by the NE CASC, USGS, or EPA. This manuscript is submitted for publication with the understanding that the United States Government is authorized to reproduce and distribute reprints for governmental purposes.

Open Access This article is licensed under a Creative Commons Attribution 4.0 International License, which permits use, sharing, adaptation, distribution and reproduction in any medium or format, as long as you give appropriate credit to the original author(s) and the source, provide a link to the Creative Commons licence, and indicate if changes were made. The images or other third party material in this article are included in the article's Creative Commons licence, unless indicated otherwise in a credit line to the material. If material is not included in the article's Creative Commons licence and your intended use is not permitted by statutory regulation or exceeds the permitted use, you will need to obtain permission directly from the copyright holder. To view a copy of this licence, visit http://creativecommons.org/licenses/by/4.0/.

\section{References}

Adamowicz, S.C., and C.T. Roman. 2005. New England salt marsh pools: A quantitative analysis of geomorphic and geographic features. Wetlands 25: 279-288.

Adamowicz, S.C., G. Wilson, D.M. Burdick, W. Ferguson, and R. Hopping. 2020. Farmers in the marsh: Lessons from history and case studies for the future. Wetland Science \& Practice 183-195.
Babson, A.L., R.O. Bennett, S. Adamowicz, and S. Stevens. 2020. Coastal impacts, recovery, and resilience post-Hurricane Sandy in the northeastern US. Estuaries and Coasts 43: 1603-1609. https:// doi.org/10.1007/s12237-020-00809-x.

Barras, J. A., S. Vebille, D. Britsch, S. Hartley, S. Hawes, J. Johnston, P. Kemp, et al. 2003. Historical and projected coastal Louisiana land changes: 1978-2050: USGS Open File Report 03-334.

Bindoff, N.L., W. W. L. Cheung, J. G. Kairo, J. Arístegui, V.A. Guinder, R. Hallberg, N. Hilmi, et al. In press. 2019: Changing ocean, marine ecosystems, and dependent communities. In IPCC Special Report on the Ocean and Cryosphere in a Changing Climate, ed. H.-O. Pörtner, D. C. Roberts, V. Masson-Delmotte, P. Zhai, M. Tignor, E. Poloczanska, K. Mintenbeck, et al.

Burdick, D.M., G.E. Moore, S.C. Adamowicz, G.M. Wilson, and C.R. Peter. 2020. Mitigating the legacy effects of ditching in a New England salt marsh. Estuaries and Coasts 43: 1672-1679. https:// doi.org/10.1007/s12237-019-00656-5.

Campbell, A., and Y. Wang. 2019. High spatial resolution remote sensing for salt marsh mapping and change analysis at Fire Island National Seashore. Remote Sensing 11: 1107. https:// doi.org/10.3390/rs11091107.

Chambers, L.G., H.E. Steinmuller, and J.L. Breithaupt. 2019. Toward a mechanistic understanding of "peat collapse" and its potential contribution to coastal wetland loss. Ecology 100: e02720. https://doi.org/10.1002/ecy.2720.

Costa, J.E., and M. Weiner. 2017. Atlas of changes in salt marsh boundaries at selected islands in the West Branch of the Westport River, 1934-2016. Buzzards Bay National Estuary Program Technical Report. Wareham, MA.

DeLaune, R.D., J.A. Nyman, and W.H. Patrick. 1994. Peat collapse, ponding and wetland loss in a rapidly submerging coastal marsh. Journal of Coastal Research 10: 1021-1030.

Duran Vinent, O., E.R. Herbert, D.J. Coleman, J.D. Himmelstein, and M.L. Kirwan. 2021. Onset of runaway fragmentation of salt marshes. One Earth 4: 506-516. https://doi.org/10.1016/j. oneear.2021.02.013.

Ewanchuk, P.J., and M.D. Bertness. 2004. Structure and organization of a northern New England salt marsh plant community. Journal of Ecology 92: 72-85. https://doi.org/10.1111/j.13652745.2004.00838.x.

FitzGerald, D.M., and Z. Hughes. 2019. Marsh processes and their response to climate change and sea-level rise. Annual Review of Earth and Planetary Sciences 47: 481-517. https://doi.org/ 10.1146/annurev-earth-082517-010255.

Ganju, N.K., Z. Defne, and S. Fagherazzi. 2020. Are elevation and open-water conversion of salt marshes connected?. Geophysical Research Letters 47. https://doi.org/10.1029/2019GL086703

Gedan, K.B., B.R. Silliman, and M.D. Bertness. 2009. Centuries of human-driven change in salt marsh ecosystems. Annual Review of Marine Science 1: 117-141. https://doi.org/10.1146/annurev. marine.010908.163930.

Himmelstein, J., O. Duran Vinent, S. Temmerman, and M.L. Kirwan. 2021. Mechanisms of pond expansion in a rapidly submerging marsh. Frontiers in Marine Science 8: 704768. https://doi.org/ 10.3389/fmars.2021.704768.

Hulsman, K., P.E. Dale, and B.H. Kay. 1989. The runnelling method of habitat modification: An environment-focused tool for salt marsh mosquito management. Journal of the American Mosquito Control Association 5: 226-234.

Kearney, M.S., and R.E. Turner. 2016. Microtidal marshes: Can these widespread and fragile marshes survive increasing climate-sea level variability and human action? Journal of Coastal Research 32: 686. https://doi.org/10.2112/JCOASTRES-D-15-00069.1.

La Peyre, M.K., B. Gossman, and B.P. Piazza. 2009. Short- and longterm response of deteriorating brackish marshes and open-water ponds to sediment enhancement by thin-layer dredge disposal. 
Estuaries and Coasts 32: 390-402. https://doi.org/10.1007/ s12237-008-9126-8.

Mariotti, G. 2016. Revisiting salt marsh resilience to sea level rise: Are ponds responsible for permanent land loss? Journal of Geophysical Research: Earth Surface 121: 1391-1407. https://doi. org/10.1002/2016JF003900.

Mcowen, C., L. Weatherdon, J.-W. Bochove, E. Sullivan, S. Blyth, C. Zockler, D. Stanwell-Smith, et al. 2017. A global map of saltmarshes. Biodiversity Data Journal 5: e11764. https://doi. org/10.3897/BDJ.5.e11764.

Oppenheimer, M., B.C. Glavovic, J. Hinkel, R. van de Wal, A.K. Magnan, A. Abd-Elgawad, R. Cai, et al. In press. 2019: Sea level rise and implications for low-lying islands, coasts and communities. In IPCC Special Report on the Ocean and Cryosphere in a Changing Climate, ed. H.-O. Pörtner, D. C. Roberts, V. Masson-Delmotte, P. Zhai, M. Tignor, E. Poloczanska, K. Mintenbeck, et al.

Perry, D.C., W. Ferguson, and C.S. Thornber. 2021. Salt marsh climate adaptation: Using runnels to adapt to accelerating sea level rise within a drowning New England salt marsh. Restoration Ecology. https://doi.org/10.1111/rec.13466.

Raposa, K.B., M.L. Cole Ekberg, D.M. Burdick, N.T. Ernst, and S.C. Adamowicz. 2017. Elevation change and the vulnerability of Rhode Island (USA) salt marshes to sea-level rise. Regional Environmental Change 17: 389-397. https://doi.org/10.1007/ s10113-016-1020-5.

Raposa, K.B., R.L. Weber, W. Ferguson, J. Hollister, R. Rozsa, N. Maher, and A. Gettman. 2019. Drainage enhancement effects on a waterlogged Rhode Island (USA) salt marsh. Estuarine, Coastal and Shelf Science 231: 106435. https://doi.org/10.1016/j.ecss. 2019.106435.

Redfield, A.C. 1972. Development of a New England salt marsh. Ecological Monographs 42: 201-237. https://doi.org/10.2307/1942263.

Roman, C.T., M.J. James-Pirri, and J.F. Heltshe. 2001. Monitoring salt marsh vegetation: A protocol for the long-term coastal ecosystem monitoring program at Cape Cod National Seashore. Coordinated by the USGS Patuxent Wildlife Research Center, Coastal Research Field Station at the University of Rhode Island, Narragansett, RI 02882 .

Salt marsh bird conservation plan for the Atlantic Coast. 2019. Atlantic Coast Joint Venture.

Schepers, L., P. Brennand, M.L. Kirwan, G.R. Guntenspergen, and S. Temmerman. 2020. Coastal marsh degradation into ponds induces irreversible elevation loss relative to sea level in a microtidal system. Geophysical Research Letters 47. https://doi.org/10.1029/ 2020GL089121

Schepers, L., M. Kirwan, G. Guntenspergen, and S. Temmerman. 2017. Spatio-temporal development of vegetation die-off in a submerging coastal marsh. Limnology and Oceanography 62: 137-150. https://doi.org/10.1002/lno.10381.

Smith, J.A.M., and M. Pellew. 2021. Pond dynamics yield minimal net loss of vegetation cover across an unditched salt marsh landscape. Estuaries and Coasts 44: 1534-1546. https://doi.org/10. 1007/s12237-020-00882-2.

Taylor, L., D. Curson, G.M. Verutes, and C. Wilsey. 2020. Mapping sea level rise impacts to identify climate change adaptation opportunities in the Chesapeake and Delaware Bays, USA. Wetlands Ecology and Management 28: 527-541. https://doi.org/10.1007/ s11273-020-09729-w.

Vincent, R.E., D.M. Burdick, and M. Dionne. 2014. Ditching and ditchplugging in New England salt marshes: Effects on plant communities and self-maintenance. Estuaries and Coasts 37: 354-368. https://doi.org/10.1007/s12237-013-9671-7.

Warren, R.S., P.E. Fell, R. Rozsa, A.H. Brawley, A.C. Orsted, E.T. Olson, V. Swamy, and W.A. Niering. 2002. Salt marsh restoration in Connecticut: 20 years of science and management. Restoration Ecology 10: 497-513. https://doi.org/10.1046/j.1526-100X.2002. 01031.x.

Watson, E.B., C. Wigand, E.W. Davey, H.M. Andrews, J. Bishop, and K.B. Raposa. 2017. Wetland loss patterns and inundationproductivity relationships prognosticate widespread salt marsh loss for southern New England. Estuaries and Coasts 40: 662681. https://doi.org/10.1007/s12237-016-0069-1.

Wetland restoration at Farm Creek Marsh. 2021. A Blackwater 2100 Project. Audubon Society. https://md.audubon.org/sites/default/ files/farm_creek_marsh_083018-web.pdf. Accessed September 23.

Wigand, C., T. Ardito, C. Chaffee, W. Ferguson, S. Paton, K. Raposa, C. Vandemoer, and E. Watson. 2017. A climate change adaptation strategy for management of coastal marsh systems. Estuaries and Coasts 40: 682-693. https://doi.org/10.1007/s12237-015-0003-y.

Williams, B.K. 2011. Adaptive management of natural resourcesframework and issues. Journal of Environmental Management 92: 1346-1353. https://doi.org/10.1016/j.jenvman.2010.10.041.

Wilson, C.A., Z.J. Hughes, D.M. FitzGerald, C.S. Hopkinson, V. Valentine, and A.S. Kolker. 2014. Saltmarsh pool and tidal creek morphodynamics: Dynamic equilibrium of northern latitude saltmarshes? Geomorphology 213: 99-115. https://doi.org/10.1016/j.geomorph.2014.01.002.

Wolfe, R. 1996. Effects of open marsh water management on selected tidal marsh resources: A review. Journal of the American Mosquito Control Association 12: 701-712.

Wolfe, R., P. Zarebicki, and W. Meredith. 2021. The evolution of saltmarsh mosquito control water management practices relative to coastal resiliency in the Mid-Atlantic and northeastern United States. Wetlands Ecology and Management. https://doi.org/10. 1007/s11273-021-09817-5. 